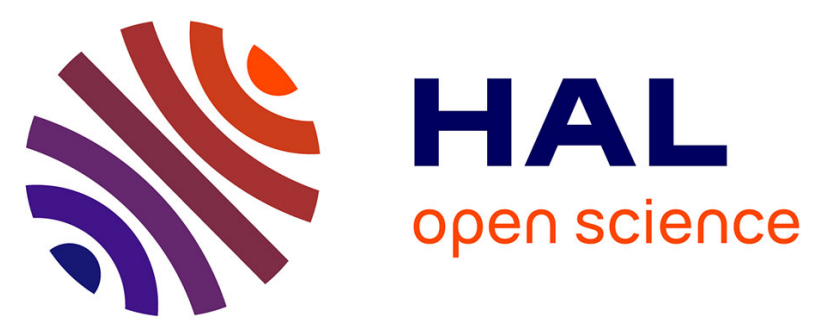

\title{
LATE HOLOCENE MONGOLIAN CLIMATE RECONSTRUCTIONS FROM LOCALLY CALIBRATED GDGT AND POLLEN TRANSFER FUNCTIONS FOR LAKE AYRAG.
}

Lucas Dugerdil, Guillemette Ménot, Odile Peyron, Isabelle Jouffroy-Bapicot, Anne-Lise Develle, Ingrid Antheaume, Salomé Ansanay-Alex, Boris Vannière, Bazartseren Boldgiv, Matthew Makou, et al.

\section{- To cite this version:}

Lucas Dugerdil, Guillemette Ménot, Odile Peyron, Isabelle Jouffroy-Bapicot, Anne-Lise Develle, et al.. LATE HOLOCENE MONGOLIAN CLIMATE RECONSTRUCTIONS FROM LOCALLY CALIBRATED GDGT AND POLLEN TRANSFER FUNCTIONS FOR LAKE AYRAG.. 30th International Meeting on Organic Geochemistry (IMOG 2021), Sep 2021, Online, France. pp.1-2, 10.3997/2214-4609.202134180 . hal-03408734

\section{HAL Id: hal-03408734 https://hal.science/hal-03408734}

Submitted on 29 Oct 2021

HAL is a multi-disciplinary open access archive for the deposit and dissemination of scientific research documents, whether they are published or not. The documents may come from teaching and research institutions in France or abroad, or from public or private research centers.
L'archive ouverte pluridisciplinaire HAL, est destinée au dépôt et à la diffusion de documents scientifiques de niveau recherche, publiés ou non, émanant des établissements d'enseignement et de recherche français ou étrangers, des laboratoires publics ou privés. 


\section{LATE HOLOCENE MONGOLIAN CLIMATE RECONSTRUCTIONS FROM LOCALLY}

\section{CALIBRATED GDGT AND POLLEN TRANSFER FUNCTIONS FOR LAKE AYRAG.}

Lucas Dugerdil a,b, ${ }^{\text {a }}$, Guillemette Ménot a, Odile Peyron ${ }^{\mathrm{b}}$, Isabelle Jouffroy-Bapicot ${ }^{\mathrm{c}}$, Anne-Lise Develle $^{\mathrm{d}}$, Ingrid Antheaume ${ }^{\mathrm{a}}$, Salomé Ansanay-Alex ${ }^{\mathrm{a}}$, Boris Vannière ${ }^{\mathrm{c}}$, Bazartseren Boldgiv e, Matthew Makou a , Vincent Grossi ${ }^{\text {a }}$, Julia Unkelbach ${ }^{\mathrm{f}}$, Hermann Behling ${ }^{\mathrm{f}}$, Jérôme Magail ${ }^{\mathrm{g}}$ and Sébastien Joannin ${ }^{\mathrm{b}}$

${ }^{\text {a }}$ Univ. Lyon, ENS de Lyon, France

${ }^{\mathrm{b}}$ Univ. Montpellier, Montpellier, France

c Univ. Bourgogne Franche Comté, Besançon, France

${ }^{\mathrm{d}}$ Univ. Savoie, Le Bourget-du-Lac, France

e National University of Mongolia, Ulaanbaatar, Mongolia

${ }^{\mathrm{f}}$ Univ. Goettingen, Germany

${ }^{g}$ Musée d’anthropologie préhistorique de Monaco, Monaco

\section{Introduction}

Pollen transfer functions are currently one of the most reliable methods for paleoclimate modelling of continental Mean Annual Air Temperature (MAAT) and Mean Annual Precipitation (MAP). Over the last few decades, molecular biomarkers have emerged as a powerful alternative to pollen transfer functions in continental settings. The fractional abundances of branched glycerol dialkyl glycerol tetraethers (brGDGTs) are a promising tool known to be related to climate parameters via the soil/lacustrine bacterial communities.

In extremely arid environments such as the mountainous areas ranging from Arid Central Asia (ACA) to Sibero-Mongolian Khangai, a coupled pollen-brGDGT climate approach has been tested to provide robust estimates of Holocene climate and environment changes. The two proxies were calibrated for both global (Naafs et al., 2017a, b) and local (NMSDB, Dugerdil et al., in press) modern datasets. The multiproxy approach was then applied to a sediment core from Lake Ayrag, Arkhangai, covering the Late Holocene.

\section{Results}

The 4,000 year cal BP sequence from Lake Ayrag documents the Late Holocene climate and human impact variations. While the globally calibrated records (both for pollen and brGDGTs, Figure 1) display a slight millennial-scale cooling, the local calibration highlights centennial-scale climate oscillations such as the Little Ice Age (LIA), Warm Medieval Period (WMP), Dark Ages Cold Period (DACP), Roman Warm Period (RWP), and the $3.8 \mathrm{kyr}$ and $4.2 \mathrm{kyr}$ events. Climate oscillations are discussed in regards to the main Mongolian human historical occupation events also documented by pastoralism proxies (anthropogenic pollen indicator and dung fungal spores bumps).

Both pollen and biomarkers show an anti-correlated trend between MAAT and MAP: over the last 4,000 ky cal BP, the warm periods (WMP, RWP) were dry and the cold periods (LIA, DACP) were wetter. Thus, the East Asian Summer Monsoon (EASM, i.e., warm and wet conditions during the summer season) seems not to influence central Mongolian climate during the Late Holocene, which stayed dominated by the Westerlies / Siberian Highs circulation conflict.

\section{Conclusions}


The EASM front oscillated since the Holocene Optimum, and its consequences for the dry ACA areas are determinant to improve our understanding of climate changes' impacts on human societies. In this context, the central mountainous part of Mongolia (Khangai range) has been set apart. At a larger scale, a climate synthesis following the same approach (brGDGT vs. pollen-inferred climate) for all of the ACA records available for the Holocene should help us to better delineate the climate systems paced by centennial to millennial oscillations and their consequences for human societies.

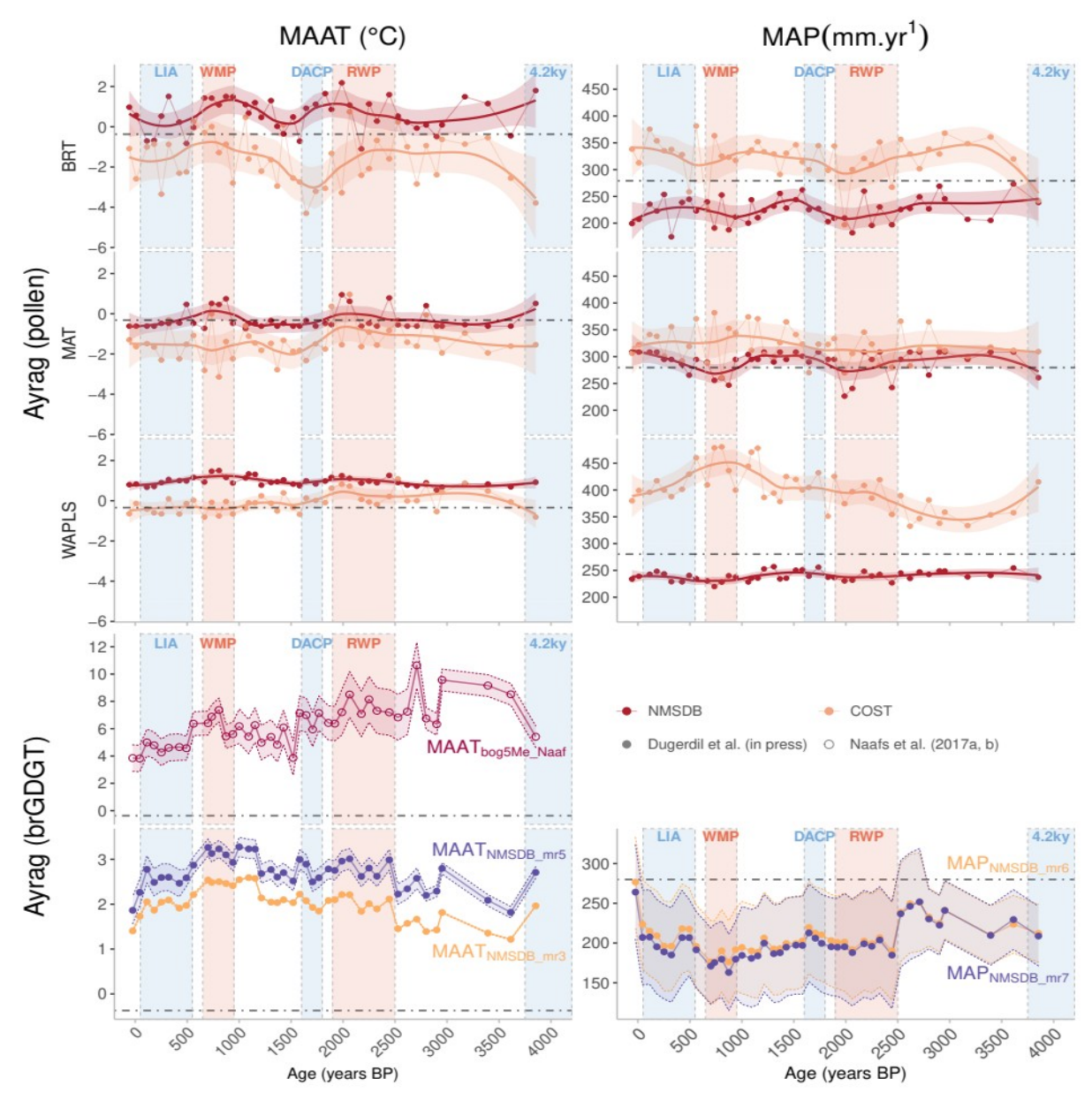

Figure 1 Comparison of MAAT (left part) and MAP inferred from pollen data with a multimethod approach, including Boosted Regression Trees (BRT), Modern Analogue Technique (MAT) and Weighted Averaging Partial Least Squares regression (WAPLS), and brGDGT from local (Dugerdil et al., 2020) to global calibrations (Naafs et al., 2017a, b).

\section{References}

Naafs, B.D.A., A.V. Gallego-Sala, G.N. Inglis, and R.D. Pancost. 2017. " Refining the Global Branched Glycerol Dialkyl Glycerol Tetraether (BrGDGT) Soil Temperature Calibration ». Organic Geochemistry 106 (avril): 48-56. https://doi.org/10/gbjssd.

Dugerdil, Lucas, Sébastien Joannin, Odile Peyron, Isabelle Jouffroy-Bapicot, Boris Vannière, Boldgiv Bazartseren, Julia Unkelbach, Hermann Behling, and Guillemette Ménot. 2020. " Climate Reconstructions Based on GDGT and Pollen Surface Datasets from Mongolia and Siberia: Calibrations and Applicability to Extremely Cold-Dry Environments over the Late Holocene ». Climate of the Past Discussions, décembre, 1-39. https://doi.org/10.5194/cp2020-154. 